Meta

Journal des traducteurs

Translators' Journal

\title{
Translators and Social Context: The Case Study of Slovakia
}

\section{Martin Djovčoš}

Volume 59, numéro 2, août 2014

URI : https://id.erudit.org/iderudit/1027479ar

DOI : https://doi.org/10.7202/1027479ar

Aller au sommaire du numéro

\section{Éditeur(s)}

Les Presses de l’Université de Montréal

ISSN

0026-0452 (imprimé)

1492-1421 (numérique)

Découvrir la revue

Citer cet article

Djovčoš, M. (2014). Translators and Social Context: The Case Study of Slovakia. Meta, 59(2), 330-359. https://doi.org/10.7202/1027479ar

\section{Résumé de l'article}

Cet article traite de la situation des traducteurs dans la société slovaque. Il examine qui traduit quoi, comment et quelles sont les circonstances de ce processus. Pour ce faire, il utilise les méthodes quantitative et qualitative de recherche. L'analyse quantitative a été réalisée au moyen d'un questionnaire et d'une analyse de corrélation des données dont les résultats ont ensuite été testés par l'analyse qualitative de 30 traductions faites par 10 traducteurs (trois textes par traducteur). Les conclusions sont ensuite confrontées aux idées des traductologues slovaques et étrangers. L'étude traite de la traduction considérée sous les aspects suivants : communication, processus de traduction, compétences du traducteur, modes d'acquisition de ces compétences (formation universitaire ou expérience pratique) et influence de ces facteurs sur la qualité du résultat. L'étude présente plus particulièrement les résultats obtenus par l'intermédiaire de l'analyse quantitative.
Ce document est protégé par la loi sur le droit d'auteur. L'utilisation des services d’Érudit (y compris la reproduction) est assujettie à sa politique d'utilisation que vous pouvez consulter en ligne.

https://apropos.erudit.org/fr/usagers/politique-dutilisation/ 


\title{
Translators and Social Context: The Case Study of Slovakia
}

\author{
MARTIN DJOVČǒ̌ \\ Matej Bel University, Banská Bystrica, Slovakia \\ martin.djovcos@umb.sk
}

\begin{abstract}
RÉSUMÉ
Cet article traite de la situation des traducteurs dans la société slovaque. Il examine qui traduit quoi, comment et quelles sont les circonstances de ce processus. Pour ce faire, il utilise les méthodes quantitative et qualitative de recherche. L'analyse quantitative a été réalisée au moyen d'un questionnaire et d'une analyse de corrélation des données dont les résultats ont ensuite été testés par l'analyse qualitative de 30 traductions faites par 10 traducteurs (trois textes par traducteur). Les conclusions sont ensuite confrontées aux idées des traductologues slovaques et étrangers. L'étude traite de la traduction considérée sous les aspects suivants: communication, processus de traduction, compétences $d u$ traducteur, modes d'acquisition de ces compétences (formation universitaire ou expérience pratique) et influence de ces facteurs sur la qualité du résultat. L'étude présente plus particulièrement les résultats obtenus par l'intermédiaire de l'analyse quantitative.
\end{abstract}

\begin{abstract}
This paper investigates the position of translators in Slovak society. It seeks an answer to the question who translates what, how and under which circumstances. To do so, it uses quantitative and qualitative methods of research. The quantitative analysis was performed with a questionnaire and data correlation analysis, whose results were then further tested via a qualitative analysis of 30 translations translated by 10 different translators ( 3 text types per each translator).' The findings are juxtaposed with the ideas of Slovak and international translation scholars. The paper deals with translation as communication, the translation process, translator's competences, the means by which these competences are acquired (formal education or practical experience) and how these factors influence the quality of translators' output. This research paper presents results gained in the quantitative analysis.
\end{abstract}

\section{MOTS-CLÉS/KEY WORDS}

traducteur, compétence, formation professionnelle, analyse quantitative, Slovaquie. translator, competence, formal training, quantitative analysis, Slovakia.

\section{Introduction}

On the basis of theoretical works dealing with the definition and nature of translation, it appears that most translation scholars and theoreticians especially in Slovakia understand translation as communication and the translator as a particular recipient as well as an expedient of a communicated text. These ideas rest mainly upon the tradition introduced by Levý and Popovič in their works. They conceived translation as 1) a mediating communication process whereby the translation functioned as a representation of the prototype/prototext or sign at face value. The processual "translation as communication" model was thus based on the general theory of modelling, theory of information and Czech/Slovak semiotics; 2) The complementary model was 
structural, comparing the two structures in terms of invariant and variable elements of the signs as systemic wholes.

Theory of translation was a cover term supposed to encompass theories of human and machine translation and theory of interpreting. Popovič (1975) integrated theory of translation into a discipline now called Translation Studies. The discipline was supposed to cover not only specific (partial) theories but also the empirical (descriptive) branch and praxeology (the applied branch), as well as terminology, methodology and historiography. ${ }^{2}$

The tradition is very vividly described by Jettmarová (2008) in her paper Czech and Slovak Translation Theories: The Lesser-Known Tradition where she argues that Western theories often misunderstand and misinterpret structuralism applied in the Czech Republic and Slovakia mistakenly confusing it with French structuralism. Following Czech and Slovak structuralism she argues that

readers/receivers themselves are an open, changing system, and so is the meaning of a message when it is undergoing the process of semiosis during reception, i.e. when becoming established as a semantic structure in the reader's mind. (Jettmarová 2008: 4)

Following these ideas Hut'ková (2011) claims that the "original/source text can be understood as a network of infinite variants of possible receptions. It is a paradigm of potential meanings resulting into complex sense" (Hutková 2011: 88; my translation). ${ }^{3}$ She further concludes that therefore, there is no universal pattern for translation or for perfect translation. In line with the tradition in translation theory or translatology as it is often called in the Czech and Slovak context, Gromová (1996) sets the basic criteria for translators' training. She considers the translator as the central part of the translation process and defines the basic set of translators' competences, which in her opinion are the following: linguistic, sociolinguistic, discourse and strategic (Gromová 1996: 20). In her later work she complements the basic requirements by adding intercultural competence (Gromová 2003: 61-62). Similar ideas may be found in Bell (1991), however, they are to be interpreted in the above mentioned context. We need to understand that Slovakia is a country with huge need for translations. According to the survey performed by the European Council of Literary Translators' Associations (CEATL) “The real 'European champions' of literary translation are the Czechs and the Slovaks with a proportion of $80 \%$ in fiction" (Fock, De Haan et al. 2008: 67). This means that as much as $80 \%$ of overall literary production consists mainly of translations. Further research conducted in 2011 by Djovčoš and Pliešovská indicated that of the overall proportion of translations from English written literatures in the period between 1989 (Velvet Revolution) and 2010, the total translation production was 51\% (Djovčoš and Pliešovská 2011: 84). This helps us understand the dominating cultural tendency and also why Slovak scholars are so interested in translators' training. We do not have exact statistics on translation of non-literary texts, but we presume that after Slovakia's access to the European Union (EU) in 2004, the situation was similar, if not even more intense. There are also scholars in Slovakia who are aware of limits of "prescriptive approach." Kusá (2005: 16-21), for example, argues that translations served various cultural, social and political purposes during different periods of history. Sometimes they were in the centre, sometimes on the periphery; sometimes they served the Church, sometimes they served its “folk." Bednárová (1994: 9), exploring the Slovak history of translation, 
points out the need to investigate translation in the context of a chain: culture - ideology - literature - translation.

When there is a great need for translations, there is a great need for translators. Translation is probably one of very few professions that most people think they can cope with. Surely, no one can restrict anyone from doing it. But as Müglová (2009: 71) notes, deprofessionalisation of the translation market in Slovakia is a serious problem and she recognises four groups of people who interfere with formally educated translators: laymen with good intentions; wanna-be experts with no selfreflection; experts from fellow disciplines; experts from distanced disciplines. Katan (2009: 131) came to similar conclusions in his research, noting that professional translators see two distinct groups that interfere with their practice: non-specialist translation amateurs and subject specialist translation amateurs. Keníž (2008: 32) finds the ideal set of competences combining translating, teaching and theoretical skills, but he himself admits that it is only hardly reachable in practice. The Slovak school of translation has developed certain rules for "adequate" translation and they were explicitly formulated by Ferenćík (1982). Although sometimes criticized, they are generally accepted, especially by the older generation of translators, as the main components of translators' competence. He puts forth the following principles as the main ones to be preserved in translation: a text integrity principle; an identity of meaning principle; an identity of form principle; a good Slovak principle (combined with the principle of a strictly functional use of substandard elements); and a principle of giving preference to the meaning in cases of conflict between the identity of the meaning and the form (Ferenčík 1982: 54-55). Currently we may find a list of competences elaborated by the European Master's in Translation (EMT) expert group who say that translators must possess the following: translation service provision competence; intercultural competence; information mining competence; thematic competence; technological competence. ${ }^{4}$ In 2011 Biloveský performed an extensive analysis of Hawking translations into the Slovak language. His books were translated by physicists and Biloveský concludes that

[i]f such texts are translated by a translator whose competence in working with the target language - Slovak is low and he lacks a basic theoretical education in translatology, he can cause illegibility of a text resulting in readers' refusal to accept such work (Biloveský 2011: 147; my translation). ${ }^{5}$

We briefly discussed the theoretical and cultural context in which we conducted the present research and tried to explain why in Slovakia often normative criteria are put on translators unlike some Western theorists who view translators as active and often political and committed agents. Thought provoking ideas on this issue are presented by Tymoczko (2007), Gentzler (2001) and Venuti (1998), but although they work with different contexts, their ideas might also be suitable for interpretation of our results. On one side we have theorists making assertions as to what translators should do and know, while on the other side we have employers also demanding what translators should do and know, and their ideas often contradict each other. One of the goals of the OPTIMALE project was

[d]etermining current and emerging competence requirements within the European translation industry, i.e. identifying the competences that employers seek when looking to employ new staff, via an online survey aimed at employers throughout the industry. ${ }^{6}$ 
We could probably continue at length in providing a list of what theorists say about translators, however, our research focus is not what translators should do or who they should be, but an attempt to determine what they actually do and who they actually are. We didn't apply the top down principle, but rather bottom up.

The main problem we are therefore currently faced with is theory's ongoing retreat from practice and vice versa. We submit that Slovak academia, among others, does not sufficiently reflect the contemporary translator's circumstances, which contributes to the lack of emphasis on such realities in the training of new translators (an exception to this is latest research on the status of translators in the EU conducted by Pym, Grin et al. 2012). In the Slovak academic environment, translation is mostly presented as a creative art, as if to automatically disassociate itself from the discussion on translation of pragmatic texts, which comprise the bulk of translators' workloads today. But far from mere transcription, translating such texts also requires creative intellectual activity. To consider translation as a product, a commodity bought and sold on the market, is seen as crass and unfit for academic discussion. We nonetheless ask: How do today's graduates in translation studies primarily make a living? We know of only a handful of translators who, in a limited sense, sustain themselves with literary translation, while the majority of translators is primarily earning a living from translating websites, promotional materials, contracts, etc. But does this imply that such texts are not worth mentioning and can be ignored? What do we know about such translations and their translators? What do we know about the circumstances of translation (not only) in Slovakia? Who actually translates these texts? Do they have the necessary competences to do so? And if so, how and where did they acquire them? From experience or from a training institution?

The results of our research could serve as a valuable starting point for further reflections on the topic or as a basis for the consideration of bringing translator training closer to translation practice. In our opinion it will be very interesting to assess the level of translators' technical and business competences. One could predict that Müglová's (2009) "wanna-be experts" will likely have well-honed marketing skills, but weaker translations skills. Indeed, thanks to their self-confidence, it is precisely they who displace educated translators on the current market. As a basic criterion of long-term employment or individual contracts, today's employers often require translators to work with computer-assisted translation (CAT) tools. Translators also have to know how to determine their rates and calculate invoices, and as far-fetched as it may sound, many graduates do not.

Though we do not see accounting and technical skills to be the translators' principal competences, few will succeed without them, and thus they are worthy of greater attention in not only research, but in the didactics of translation and interpreting as well.

\section{Research design and procedures}

Our original research consisted of two main parts: quantitative and qualitative. The quantitative analysis consisted of a descriptive analysis involving questionnaire and correlation analysis. In our qualitative analysis we sent three different texts (essay, popular-scientific text, scientific text) to ten translators as a translation assignment, without letting them know that texts would be used for analysis. We paid their 
standard fee for the translations and we observed how they usually communicate with the client. We then analysed the translations and compared output with answers from the questionnaire and results of correlation analysis. This procedure enabled us to gain more or less objective results and create a profile of the average translator in Slovakia.

\subsection{Goal and the hypotheses}

The goal of the present study is to present a comprehensive survey of the work translators actually do, including contemporary factors that influence quality.

We shall determine who translates what, how and under which circumstances. We will seek the answer to the first pair of questions through quantitative research methods (though the scope of this article does not extend to a detailed discussion of their results), and the second pair through qualitative research methods by means of an analysis and interpretation of translations.

On the basis of the preliminary evaluation of the questionnaire (which we describe in more detail in the Methods section of the quantitative analysis), along with the data that could be processed statistically, we have devised the following ten hypotheses:

H1: Older translators charge higher rates than younger translators.

In this case we predict that more experienced translators who have worked in the sphere of translation longer charge higher rates for their services. We divided the translators into various age categories based on their responses to the questionnaire.

H2: Respondents who have studied translation charge higher rates than those with other educational backgrounds.

We predict that professionals with formal education in translation demand higher compensation than those without. We shall observe whether the deprofessionalization of translating has influenced this relation as well, and if so, in what way.

H3: Respondents who translate between less widely spread languages and Slovak charge higher rates than those who translate between Slovak and English or German.

We categorized language combinations according to their prevalence based on the table below entitled "Translated Languages," and for the sake of this hypothesis, we consider English (39\% of the respondents) and German (15\%) to be widely used languages. Most of the respondents reported translating a combination of various languages usually including English, and we have thus classified English in combination with rarer languages, such as Scandinavian ones, as a less widely used combination. We took a similar approach in hypothesis H10.

H4: Respondents who have studied translation consider translation theory more useful than those with other educational backgrounds.

Logic dictates that translators with formal education in their field would have a more favourable relationship to theory than those without. We will thus observe what influence education has on translators' attitudes to theory. We divided respondents' reactions into two categories: a) yes and b) no or other. No or other 
includes respondents who explicitly answered no or I am not familiar with translation theory, but also those who expressed a negative attitude to theory in the other field.

H5: Respondents with tertiary education are more likely to take a comprehensive process-based approach to translation than those without it.

We admit that it would be more appropriate to use formal translation education as a variable in this hypothesis instead of general tertiary education, but the file containing that information was unfortunately damaged beyond repair. Nonetheless, as the university-educated translators include the $44.8 \%$ of the total with a formal degree in translation, it will remain possible to at least estimate their final proportion. For the purposes of the study, specifically question 19, we define a comprehensive process-based approach to translation as follows: I read the text several times, look up unknown terms, seek advice from an expert and only then do I finalize the translated text.

H6: Respondents who consider translation theory useful are more likely to take a comprehensive process-based approach to translation than those who do not consider it useful.

This relation will allow us to determine whether those respondents who consider translation theory useful actually apply it, and if so, to what degree.

H7: Younger translators are more likely to lower their rates in response to competitive pressure than older translators.

We expect that translators who have been in the market longer and have a constant and sufficient workload do not need to lower their rates when faced with competition.

H8: Respondents who have studied translation are younger than those with other educational backgrounds.

This hypothesis proceeds from the proliferation of institutions offering formal translation education since the 1990s.

H9: Respondents whose translation work is not primarily motivated by financial gain take a more comprehensive approach to translation than those who are primarily motivated by financial gain.

Here we presume that respondents who translate more for pleasure than profit take a more rigorous approach than those who need to make a living and thus have more limited time. This could also have the reverse prediction: when your living depends on it, you might seem to have a strong incentive to be rigorous. On the other hand, you will probably have less time to focus on all details of your translation in such circumstances. This question provides very interesting stimulus for further debate on factors influencing the quality of translations in general.

H10: Translators of less widespread languages are less likely to lower their rates in response to competitive pressure than translators of English and German.

We imagine two possible scenarios behind this hypothesis: Either translators of less widely used languages are able to demand higher rates due to their scarcity, or they are forced to settle for lower rates due to the comparable scarcity of their clients. 
All ten hypotheses were tested with quantitative research methods using contingency tables. In the qualitative analysis we were able to confirm hypotheses $\mathrm{H} 2$, H4, H6 and H9 through a comparative analysis and interpretation of respondents' translations.

\subsection{Methods}

We shall apply statistical methods to the data in the quantitative analysis, consisting of two parts: a descriptive analysis and a correlation analysis. In the first we will observe the responses to individual questions from the questionnaire and interpret them in a broader context, compared with the results of a similar study conducted by Katan (2009) in 25 countries (not including Slovakia) with approximately 1,000 respondents.

As this is the first study of its kind in Slovakia, we had no other research to refer to or compare data with. To collect our data we used a questionnaire survey, administered to 148 respondents from August to October 2010. The questionnaire consisted of 25 questions, of which 13 were closed-ended, 3 were open-ended, and 9 were semiopen-ended. We arranged the fields in a way that the data lent itself to subsequent correlation analysis. Thus we used the questionnaire as a means to identify variables and formulate hypotheses (described above under the heading Goals and Hypotheses) as well as a complement to the correlation analysis.

The questionnaire was available on the Edotaznik ${ }^{7}$ website and was also distributed to publishers, translation agencies, freelance translators and interpreters (via ProTranslator ${ }^{8}$ ), university staff, the Field Office for Multilingualism of the Representation of the European Commission in the Slovak Republic in Bratislava, international companies and professional organizations for translations (JTP, SSPOL, SSPUL, SAPT), in order to obtain a maximally diverse cross section of people who translate. In determining the questions for the survey, we consulted with university teachers, owners and employees of translation agencies and our translator colleagues. The semi-open-ended and closed-ended questions were automatically evaluated and visualized as pie charts. Open-ended questions were evaluated manually. We were focused on determining the basic profile of today's average translator, their technical and business competences, as well as their motivation, reaction to market pressures and application of theory in practice. Each category consisted of the following data:

1) Basic profile:

$\begin{array}{ll}\text { 1) Basic profile: } & \text { Level of education } \\ & \text { Field of study } \\ & \text { Field of earned degree } \\ & \text { Specialization } \\ & \text { Age } \\ & \text { Gender } \\ & \text { Translated languages } \\ & \\ & \text { Use of CAT tools } \\ & \text { Reason for not using CAT tools } \\ & \text { Other software }\end{array}$


3) Business competences:

4) Motivation:

6) Theory and practice:
Billing method

Standard page

Method of calculating a standard page

Rate per standard page

Legal form of business

Motivational factor

Evaluation and quality of translation

Grounds for turning down offers

5) Market pressures vs. quality: Time vs. quality

Stress vs. quality

Response to competition

Translation process

Quality control

Usefulness of theory

(my translation)

We focused on practical areas primarily due to theory's relative neglect to date of translation's contemporary context, which we feel deserves more attention. It is difficult to implement changes to, for example, translator education if we are unaware of the current situation in translators' actual environment. To ensure the credibility of our data, we compared the interpretation of our results with those of Katan's 2009 study, supplemented by information from translators' internet profiles and partial studies of translation and interpreting students in Banská Bystrica (see Fugová 2001 and Tešlárová 2011).

To confirm our hypotheses, formulated on the basis of the processable data, we used nonparametric statistical tests, given that our quantitative research method (a questionnaire) limited us to nominal and ordinal data. Testing is to draw conclusions about a population based on data yielded by selected sections of that population ( $\mathrm{n}=$ our study). It is an algorithmic process used to confirm or refute a hypothesis (Sihelský 2008).

In our study, we will make primary use of the chi-square test $\left(\chi^{2}\right)$, proceeding from a frequency table and testing the null statistical hypothesis that the values in individual categories will match the expected (theoretical) values.

\section{Data analysis with regard to the hypothesis}

This section of the article is focused on presenting and interpreting the concrete results of the study. We first present the results of the survey and the correlation analysis, and at the end of the quantitative analysis we summarize the findings following from it.

\subsection{Descriptive analysis}

In this part we describe and interpret the respondents' answers to the survey according to the areas defined in the Methods section (2.2). As stated above, we will compare our results with those of Katan, who conducted a study of approximately 1,000 translators 
and interpreters from 25 countries, which amounts to roughly 40 respondents per country. Our study involved 148 respondents, though we were only able to use a sample of 138 or less for our correlations, as not all the study's participants opted to answer every question in the survey.

\subsubsection{Basic profile}

In this part of the questionnaire we attempted to determine who translates and what is translated, surveying respondents' level of education, specialization (literary or specialized translation), age, gender and the languages they translate most. The results of several survey questions were quite unexpected.

TABLE 1

Level of education

\begin{tabular}{|l|r|}
\hline Secondary school & $5 \%$ \\
\hline Currently studying & $9 \%$ \\
\hline University degree & $86 \%$ \\
\hline
\end{tabular}

TABLE 2

Field of study

\begin{tabular}{|l|r|}
\hline $\begin{array}{l}\text { Translation and interpreting (Nitra, Bratislava, Bystrica, Prešov), } \\
\text { various languages }\end{array}$ & $44.8 \%$ \\
\hline Languages, mainly teaching & $33.5 \%$ \\
\hline Business & $8 \%$ \\
\hline Technical fields (engineering, IT, electronics, construction) & $5 \%$ \\
\hline Natural sciences & $5 \%$ \\
\hline Other (performing arts, international relations, social work) & $5 \%$ \\
\hline Theology & $2 \%$ \\
\hline
\end{tabular}

Interpreting these results will allow us to quite clearly formulate conclusions on the basis of the actual data. The results show that $44.8 \%$ of people who translate in Slovakia are formally-educated translators. The second major group is composed of people with a degree in language teaching. Accounting for the majority view among experts that a translator's principal competence is bilingualism/language proficiency, the statistical results are very positive, given that $77 \%$ of the people who translate have formal training in languages whereas those without such education comprise a "mere" 33\%.

Obviously, aside from language competence, the process of translation places a great deal of other demands on the translator, which those not versed in translation studies either ignore entirely or, ideally, acquire and apply intuitively. At this juncture allow us to quote a comment from a particular respondent's answer to the question on the relation between theory and practice, which was: "15 years of experience in the field is a far greater asset than theory." If nothing else, this certainly opens the floodgates to a most likely endless discussion. The results also confirm the phenomenon of holders of teaching degrees going into translation and vice versa, seeing that language teachers comprise $33.5 \%$ of the respondents. On this point we refer to an initiative by the organization Pont Francophone [Francophone Bridge] ${ }^{9}$ and the 
Department of Romance Studies at the Faculty of Humanities of Matej Bel University in Banská Bystrica, spearheaded by students Zuzana Kraviarová and Martin Pleško, who on 30 November 2010 and 2011 organized an event entitled "Učitel'prekladatelom, prekladatel'učitelom" [Teachers who translate, translators who teach]. Geared towards students and prospective students of both translation and teaching, the event was focused on explaining and reducing tension arising from the particularities of specific professions.

Katan's study (2009: 120) showed similar results, with slightly less than half of the respondents holding degrees in translation. But when they extended this to translators with any language-related degrees, the result was $73 \%$, remarkably close to the $77 \%$ established in our study. In Katarína Fugová's bachelor's thesis (2011), a study conducted on the translators' professional networking site ProZ, ${ }^{10}$ only 44 out of the 100 respondents held translation degrees, which yet again corresponds to our findings.

In our supplementary study of the Slovak Society of Translators of Scientific and Technical Literature (SSPOL) ${ }^{11}$ and Prekladatelia ${ }^{12}$ websites, only roughly $20 \%$ of 394 randomly selected registered members explicitly stated that they had a degree in translation. Note, however, that even many prominent Slovak translation theorists and translators do not explicitly state their degree in translation, most referring to a language degree in general. One possible explanation for this is the multiplication of translation studies programmes that took place in 1990s Slovakia. ${ }^{13}$ Therefore we may say that the younger generation of translators is more likely to have a degree in translation and interpreting. In any case, the ratio of formally educated translators and interpreters is relatively low. Perhaps the lack of formal education is the reason why as much as half of Katan's respondents (2009: 138) put greater stock in the source text than the target text and showed disregard for the recipient. In other words, they translated the original literally. Pym for example says, that "[u]ntrained translators may work faster and more efficiently because they know less about complex theories." However, he further adds: "And public theories can help foster awareness of the complexities of translation, thus enhancing the public image of translators and interpreters (Pym 2010: 4; italics by the author).

Of course, the focus on "word for word" translation may stem from several other factors, such as various ethical approaches to the text, but we doubt that the majority of translators apply such theories in practice on an everyday basis as will be investigated later in this paper. But, as we will show, a translation degree is no guarantee of a quality translation, but rather a precondition of one.

TABLE 3

Specialization

\begin{tabular}{|l|r|}
\hline Non-literary translation & $62 \%$ \\
\hline Both & $24 \%$ \\
\hline Other & $8 \%$ \\
\hline Literary translation & $3 \%$ \\
\hline
\end{tabular}

The results of these statistics are generally unsurprising. Translation of literary works for publishing companies, as generally expected, plays a minor role, though it is interesting just how low the percentage actually is. One interesting figure is those 
who specialize in both types of translation, aptly described in one respondent's comment in the "Other" field: "I translate specialized texts to make a living; translating literature is where my true interest lies." From this statement one could deduce that translators are interested in literary translation, but do not consider it a way to support themselves, since it has to be supplemented with other types of translation.

Comparing these results with Katan's (2009: 119) proves interesting yet again. Katan also presents the results of Vande Walle's study, in which only $1 \%$ of respondents translated literature (Vande Walle 2007, cited by Katan 2009: 120). But their comments on individual questions go to show that in their work many translators solely pursue the goals of their employer, mainly serving its in-house needs. The question is if such "informative" translations truly require professional translators, who are generally seen as expensive. In our opinion they do not, at least in the case of sight translation of business correspondence, or one-time "subliminal" translation, to give listeners or readers the gist of a foreign-language text. Indeed, for these purposes an online translation site may suffice, and this is among our reasons for not including such translators in our qualitative analysis. But if such a translation is intended as an official company document, for example, we would recommend a professional translator, as an unprofessional translation in this case can blemish the company's image and fail to meet the public's demands for high-quality texts.

TABLE 4

Age

\begin{tabular}{|l|l|}
\hline up to 30 & $49 \%$ \\
\hline $31-40$ & $34 \%$ \\
\hline $41-65$ & $17 \%$ \\
\hline
\end{tabular}

The study included a truly diverse sample of translators in terms of age, ranging from 22 to 65 years of age. The relative majority of respondents were up to 30 years old, which could be attributed to the aforementioned establishment of many translation and interpreting programmes in 1990s Slovakia; we will address the quality of these graduates later in the paper. The low percentage of respondents in the 41-65 years range may have resulted from the fact that the questionnaire was only accessible online, possibly discouraging those older translators with weak computer skills from filling it out. For comparison we again refer to K. Fugová's study, where the most respondents were in the 31-40 years range, comprising $46 \%$ of the total (Fugová 2011: 27). One problem that arose in our study was that some respondents declined to state their age. It will be interesting to see whether age correlates with any of the other responses, which we will determine in the correlation section of the quantitative analysis.

TABLE 5

Gender

\begin{tabular}{|l|l|}
\hline Male & $30 \%$ \\
\hline Female & $70 \%$ \\
\hline
\end{tabular}

These results confirmed our general expectation that most people who translate are women. We found similar ratios in our study of translators' profiles on the Slovak 
Society of Translators of Scientific and Technical Literature (SSPOL) and Prekladatelia websites (see notes 10 and 11). In our sample of 394 translators, 25\% were men and $75 \%$ were women; incidentally, most of the men did not attest to having a translation degree. Surely the influence of gender on translation performance is partially rooted in neuropsychological differences, which would require its own extensive research.

From a neuropsychological perspective, it is nonetheless worth noting that in our personal experience, successful male translation students tend to play a musical instrument. In addition, in one of the experiments we have conducted during simultaneous interpreting seminars, non-verbal distractions enhanced interpreters' concentration, while verbal distraction diminished it. This is most likely related to the connection between the brain's hemispheres and the activation of its speech centres, but remains an elusive and very interesting area that merits greater attention and more thorough study in cooperation with neuropsychologists. Of course, there are many more aspects that can be added when discussing gender and translation and mainly how rates of pay depend on the gender. However, the given topic needs more thorough investigation. The research conducted by Pym, Grin et al. (2012: 86) discussed possible reasons of female predominance on the translation market in more detail.

In our analysis of translated languages, language combinations involving English unambiguously dominated. Similar findings were reported by Katan (2009: 117) (with English translators comprising more than 60\% of respondents) and Fugová (2011:28) (with 43\%). It is necessary to realize that those studies were conducted on much more geographically diverse samples, which clearly confirms English's international dominance. On the one hand this information could be interpreted as a reason for students to focus on less widely used languages, as they may represent a potentially lucrative niche in the market, but it could also signal a decrease in non-English texts, given English's rising status as a lingua franca among non-native speakers. Our own experience tends to favour the second conclusion. In any event it will be interesting to observe the correlation between the translators' languages, rates and responses to competition. For statistical purposes, we have categorized English and Germany as widely used languages and the rest as less widely used languages. We are aware that this generalization may markedly distort our results, but it was a necessary condition of our method of statistical processing.

TABLE 6

\section{Translated languages}

\begin{tabular}{|l|c|}
\hline English & $39 \%$ \\
\hline German & $15 \%$ \\
\hline Czech & $9 \%$ \\
\hline Russian & $7 \%$ \\
\hline French & $7 \%$ \\
\hline Spanish & $6 \%$ \\
\hline Italian & $5 \%$ \\
\hline Polish & $4 \%$ \\
\hline Other Slavic languages & $2 \%$ \\
\hline Scandinavian languages & $2 \%$ \\
\hline Hungarian & $1 \%$ \\
\hline
\end{tabular}




\begin{tabular}{|l|l|}
\hline Serbian & $1 \%$ \\
\hline Dutch & $1 \%$ \\
\hline Middle Eastern languages & $1 \%$ \\
\hline Ukrainian & $0 \%$ \\
\hline Belarusian & $0 \%$ \\
\hline Croatian & $0 \%$ \\
\hline
\end{tabular}

\subsubsection{Technical competences}

Our research pointed out the importance of translator's technical competence, which although addressed in many newer publications (some of them are listed in the references), is often being neglected by traditional theories on translation. By no means do we consider it to be the primary translator's competence, but we have to recognize that today's market, at least in Slovakia, demands not only an educated, professionally savvy translator, but one who can translate quickly and work with various computer programs. Still, as our research pointed out in qualitative analysis, the quest for speed often leads to routine, hackery and literal translation. Certain translation agencies even list proficiency with CAT tools as one of their hiring criteria. The OPTIMALE survey signals the fact that $76 \%$ of TSP employers find it to be essential or very important. ${ }^{14}$

For purposes of our study, we mainly focused on determining respondents' level of proficiency and use of CAT tools and other software. We were also interested in why certain translators refuse to use these software tools.

In our questionnaire, respondents could choose from a list of CAT tools that translation agencies cited as the most commonly used. As expected, Trados and Wordfast were the most commonly used CAT tools. Those who marked "Other" mentioned OmegaT, Anaphraseus, Across, Déjà Vu and several others. Particularly noteworthy is the high number of translators who do not use any such tools. As also shown in our qualitative analysis, it seems that use of these tools often leads to literalness, however, and in Slovakia we need to conduct more thorough research on text types suitable for such type of translation.

\section{TABLe 7}

\section{CAT Tools}

\begin{tabular}{|l|r|}
\hline Trados & $20 \%$ \\
\hline Wordfast & $12 \%$ \\
\hline Other & $9 \%$ \\
\hline SDLX & $8 \%$ \\
\hline Transit & $4 \%$ \\
\hline Memoq & $1 \%$ \\
\hline IBM-TM & $0 \%$ \\
\hline Logos Mneme & $0 \%$ \\
\hline None of the above & $46 \%$ \\
\hline
\end{tabular}

The following table presents the most common reasons translators cited for not using CAT tools. 
TABLE 8

Use of CAT tools

\begin{tabular}{|l|r|}
\hline I don't know how they work & $38 \%$ \\
\hline I don't consider them useful & $17 \%$ \\
\hline They slow my work down & $5 \%$ \\
\hline They are not exact & $7 \%$ \\
\hline I use CAT tools & $32 \%$ \\
\hline
\end{tabular}

TABLE 9

Other software

\begin{tabular}{|l|c|}
\hline Microsoft Word (advanced user) & $46 \%$ \\
\hline Photoshop & $18 \%$ \\
\hline Adobe Professional & $17 \%$ \\
\hline OCR software (Abbyy Fine Reader, Solid Converter) & $11 \%$ \\
\hline Corel & $4 \%$ \\
\hline None of the above & $3 \%$ \\
\hline Other & $1 \%$ \\
\hline
\end{tabular}

According to these results, we can infer that translators' technical competence is generally good in terms of usual computer literacy seeing that only $3 \%$ of respondents reported using none of the listed programs. It is also worth noting the high percentage of Photoshop users, which is in our opinion connected with the widespread use of digital cameras and subsequent editing. We also surmise that the respondents' computer literacy is connected to their particular specialization (translation of technical plans, work with PDF documents, etc). In any case, we are of the mind that a freelance translator who translates a wide variety of texts, dictated by the whims of the market, should have a grasp of as many programs as they can, as this allows them greater flexibility. It is also worth considering improving the implementation of computer training for future translators, though naturally not at the expense of translation studies.

Regarding the use of CAT tools, the situation is grimmer, with $46 \%$ of respondents not using any of the listed programs (this may include those who use other programs, but if so, most likely an insignificant percentage). This data partially undermines the pessimistic claims that "machines will soon take the place of human translators" and that translation without CAT tools is no longer possible. Paradoxically, it also supports them when juxtaposed with the table below on response to competition, where translators noted the use of CAT tools as a competitive advantage. In any case, it is likewise worth considering the wider introduction of CAT tools into the didactics of translation. Machine translation (MT) is also being mentioned more often mainly in connection with post editing as it is supposed to increase productivity of translator's work. OPTIMALE survey for example found out that $28 \%$ of translation services provider (TSP) employers require MT post-editing skills (see note 13). Very stimulating insights on this issue may be found in works of Teixeira (2011), Yamada (2011), Guerberof-Arenas (2009) or generally in the Proceedings of the $8^{\text {th }}$ International Natural Language Processing and Cognitive Science (NLPCS) Workshop (Sharp, Zock et al. 2011). Pym (2013) also deals with changing demands on translator's competence in the age of machine translation. It is worth considering 
broader introduction of such tools into the academic environment. However, as we mentioned before, a purely technical approach to the process of translation may be dangerous and lead to automatic transfer of words if it isn't applied carefully. Some indications of this fact have been displayed by our research in the qualitative part of our analysis, but that will be the subject of another article.

\subsubsection{Business competence}

The next broader area we studied was the translators' business competence. In our view, such skills are often marginalized in academic contexts, despite this being a possible reason why educated translators often lack the "killer instinct" necessary to penetrate the translation market. We therefore focused on determining respondents' method of price calculation, their familiarity with the concept of the "standard page," their rate per standard page and their legal form of business.

TABLE 10

Method of price calculation

\begin{tabular}{|l|c|}
\hline Per target standard page & $50 \%$ \\
\hline Per source standard page & $16 \%$ \\
\hline Per source word & $13 \%$ \\
\hline Per target word & $7 \%$ \\
\hline Other & $7 \%$ \\
\hline I don't translate for money & $6 \%$ \\
\hline
\end{tabular}

It is quite clear from the translators' responses that the most prevalent form of billing is based on the classic standard page, accounting for $66 \%$ of the respondents if we combine the source and target standard page groups. Of course this could also be due to the relatively low use of CAT tools (46\%), which typically calculate rates per word. The responses under "Other" also proved interesting, often referring to an hourly rate or a fixed monthly fee. Finally, some respondents always conform to their clients' needs.

Anticipating that the standard page would be the most common form of billing, we were interested in how people who translate most often would calculate one.

TABLE 11

\section{Price calculation}

\begin{tabular}{|l|c|}
\hline Characters including spaces divided by 1800 & $63 \%$ \\
\hline Characters without spaces divided by 1500 & $14 \%$ \\
\hline Characters without spaces plus word count divided by 1800 & $11 \%$ \\
\hline Other & $7 \%$ \\
\hline I don't know how to calculate a standard page & $4 \%$ \\
\hline
\end{tabular}

This information will obviously be useful to translation clients, though to teachers of translation praxeology as well, as an illustration of the variety of ways to calculate a standard page. We do not expect this factor to have any influence on the quality of the translation itself. 
TABLE 12

Rate per standard page

\begin{tabular}{|l|r|}
\hline$€ 7-10$ & $41 \%$ \\
\hline$€ 10-15$ & $37 \%$ \\
\hline$€ 15-20$ & $11 \%$ \\
\hline Less than $€ 7$ & $7 \%$ \\
\hline More than $€ 20$ & $4 \%$ \\
\hline
\end{tabular}

In this case we are primarily interested in correlations between price and quality, age and price, education and price, etc., and our findings in this regard are presented in the correlation section of the quantitative analysis. Though the present study does not extend to the influence of region on price, this could be a fruitful avenue for subsequent research.

The following table presents the variety of legal forms of business utilized by translators. $17 \%$ reported not using any of the suggested forms. We presume that this group consists of students and in-house employees of translation agencies and international companies.

TABLE 13

Form of business

\begin{tabular}{|l|l|}
\hline I have a Trade licence $^{15}$ & $45 \%$ \\
\hline I work on the Agreement (unregulated) & $26 \%$ \\
\hline I run my own Ltd. & $12 \%$ \\
\hline None of the above & $17 \%$ \\
\hline
\end{tabular}

\subsubsection{Motivation}

We consider translators' motivation to be one of the fundamental pillars of further research into the translator's personality. It is also interesting to explore the relationship between motivation and the type and quality of their translations. The table below presents the surprising finding that only $31 \%$ of translators are primarily motivated by financial gain. In total as much as $37 \%$ of respondents translate for professional and personal satisfaction; that is to say, they consider translation their calling.

TABLE 14

Primary motivational factor

\begin{tabular}{|l|l|}
\hline Financial reward & $31 \%$ \\
\hline Professional satisfaction & $23 \%$ \\
\hline Text type & $20 \%$ \\
\hline Personal satisfaction & $14 \%$ \\
\hline Type of customer & $12 \%$ \\
\hline
\end{tabular}

This section of the questionnaire was intended to determine whether translators translated better if they were better financially compensated. 
TABLE 15

Price and quality

\begin{tabular}{|l|r|}
\hline I always do my best & $72 \%$ \\
\hline Probably & $11 \%$ \\
\hline Definitely not & $7 \%$ \\
\hline Definitely & $6 \%$ \\
\hline Probably not & $3 \%$ \\
\hline
\end{tabular}

We regard the results in the above table as highly positive, with $72 \%$ of respondents claiming that they always do their best; in other words, quality is their primary concern. To what degree such determination leads to quality translation is debatable, considering the wide range of competence among translators, but we shall leave such questions to the study's qualitative portion.

TABLE 16

Reasons for refusing a translation

\begin{tabular}{|l|r|}
\hline Lack of time & $31 \%$ \\
\hline If I know the customer is not to be trusted & $24 \%$ \\
\hline Unknown terminology & $23 \%$ \\
\hline Insufficient financial compensation & $20 \%$ \\
\hline I never refuse work & $2 \%$ \\
\hline
\end{tabular}

We expect the study's conclusions to include a direct relationship between rejecting work and responding to competitive pressure.

\subsubsection{Market pressures vs. quality}

TABLE 17

Time vs quality

\begin{tabular}{|l|r|}
\hline The less time, the lower the quality & $55 \%$ \\
\hline Time doesn't influence quality in any negative way & $32 \%$ \\
\hline The less time, the higher the quality & $2 \%$ \\
\hline Other & $11 \%$ \\
\hline
\end{tabular}

Among the most salient responses cited text type as one of the deciding factors entering the equation of time versus quality. Some respondents also commented that they give themselves as much time as they need. These are most likely translators of rarer languages, as supported by our correlative interpretation of the results. Naturally, the type of text also plays a role in this context.

Among the findings in the table below, our attention is particularly drawn to the similar proportion of respondents reporting a positive influence of stress on the quality of their translations as those reporting a negative one. This is most likely due to the variety of psychological personality types, a possible point of departure for future studies. We presume that those who claim not to be influenced by stress are translators of less widely used languages and those primarily motivated by personal and professional satisfaction. 
TABLE 18

Stress and quality

\begin{tabular}{|l|c|}
\hline Negative influence - I make more mistakes under stress & $38 \%$ \\
\hline Positive influence - I work more effectively under stress & $33 \%$ \\
\hline Stress has no influence on me & $22 \%$ \\
\hline Other & $7 \%$ \\
\hline
\end{tabular}

The answers in the "Other" category can be summed up in a single quote from one of the respondents:

[...] it depends on various circumstances, or rather types of stress; I don't generally work under stress, I first try to overcome it, which sometimes only takes a little while. (my translation) ${ }^{16}$

The figures below, based on the proportional distribution of the respondents' individual reactions, clearly reflect their various approaches to dealing with competitive pressure. Particularly encouraging is the high percentage of those who do not accept work in the absence of adequate compensation, though this could include those whose main source of income is not translation, who can thus afford to turn down work. In any event, we see this as a positive indicator towards the improvement of professional awareness and the translator's social standing. Translators' steadfastness regarding their rates was also partially confirmed by our email communications with translators when we ordered the translations for our qualitative analysis. When asked about the possibility of a reduced rate (justified by our limited funds as a student), one of the respondents claimed that recommended rates range from 21 to 23 euros:

I try to adhere to recommended rates, which are between $€ 21$ and $€ 22$ per standard page (1800 keystrokes) here in Slovakia. This price is only half of the EU standard. $€ 10$ reflects prices circa 15 years ago. (my translation) ${ }^{17}$

As this quotation came directly from the response of one of the respondents (we do not acknowledge the source so as to preserve anonymity of participants), we don't know where he gotthis information from. This particular translator is member of the Czech/Slovak Union of Interpreters and Translators (JTP) and refused the translation after our request for a lower rate. We need not go into the dubiousness of his actual claims here. This is nonetheless an example of a phenomenon we discuss in the correlation analysis: translators without a translation degree charge more than those with one. Logically, one would say that it would be exactly the opposite. However, apart from the correlation analysis this fact was also confirmed by email communication with translators that took part in qualitative analysis, where we ordered (as mentioned in the introduction) translation of three different text types by ten different translators with various background. We than observed how factors investigated in the questionnaire (education, technical competence, price, etc.) influence communication with the client and the actual translation. More detailed discussion on this conclusion will be presented in $\mathrm{H} 2$ (section 3.2.2).

Respondents' comments in the "Other" field can be summed up with the following quote: "I don't feel the need to reduce my rates, since my combination of expertise, quality translation and proficiency with CAT tools is unique in Slovakia" (my translation). ${ }^{18}$ In other words, translators' attempts to address competitive pressure by 
raising their qualifications, though in certain cases they do lower their prices, such as when they are short of work. Given the high percentage of translators (46\%) who do not use them, we are interested in observing to what degree CAT proficiency represents a competitive advantage, and in the light of our data and the hiring criteria of translation agencies as well as in line with OPTIMALE findings, it appears that it does indeed.

TABLE 19

\section{Competition}

\begin{tabular}{|l|r|}
\hline I lower my rates & $9 \%$ \\
\hline I don't decrease my rates; if I am not offered an adequate reward, I turn the job down & $48 \%$ \\
\hline Competitive pressure doesn't concern me; there are only a few of us in my field & $6 \%$ \\
\hline Competition doesn't concern me; I translate because I enjoy it & $25 \%$ \\
\hline Other & $12 \%$ \\
\hline
\end{tabular}

\subsubsection{Theory and practice}

We were particularly interested in the reactions to this section, considering that debates on the application of theory in practice generally weigh against the former. We briefly explained what we meant by "theory" in the introduction to our paper, but we shall now provide further explanations focused on the process of translation. It is most usually associated with translation shifts introduced by Popovič in 1975 and translation process introduced by Levý in 1963 and further elaborated by Vilikovský in 1984. Levý (1963) speaks about three phases of translation: Understanding of the source text; Interpretation; Restyling. Vilikovský (1984) alters them slightly and mentions: Reception and Interpretation; Strategy; Reproduction. In other words, these phases could be explained as "I read the text several times, look up unknown terms, consult an expert in the translated field and only then finalise the translated text." We decided to use this wording as we supposed that if we used terms as introduced by mentioned scholars, our research could discourage formally untrained translators to take part in it. We therefore wanted to determine how translators actually proceed in producing a translation, for example whether they check their own work in accordance with standard EN 15038, ${ }^{19}$ given that EU ordinances often influence people who translate much more than academia does.

Comparing results of the survey we see that as many as $68 \%$ of respondents consider theory useful, but only $15 \%$ of them read the text several times, look up unknown terms, consult an expert in the translated field and only then finalise the translated text. These two results would appear to contradict one another, chiefly from the perspective of mentioned Slovak theoretical tradition. $40 \%$ of respondents simply begin translating straight away, addressing problems along the way. Of course we realize that this decision also involves the aforementioned factors of time, stress and familiarity with the topic. It is interesting to note that since these questions did not immediately follow one another, the respondents presumably failed to notice the contradictory nature of their responses. In short, while a significant majority consider theory useful, most of them do not apply it effectively in practice. We will return to this conundrum in more detail in the evaluation of our hypotheses. 
TABLE 20

\section{Process of translation}

\begin{tabular}{|l|c|}
\hline $\begin{array}{l}\text { I just skim through the text and translate immediately; if there's something I'm not sure } \\
\text { about, I look it up }\end{array}$ & $41 \%$ \\
\hline I start translating immediately and address problems as I go & $26 \%$ \\
\hline $\begin{array}{l}\text { I read the text several times, look up unknown terms, consult an expert in the translated } \\
\text { field and only then do I finalise the translated text }\end{array}$ & $15 \%$ \\
\hline It depends on how much time I have and how much the client offers & $13 \%$ \\
\hline Other & $5 \%$ \\
\hline
\end{tabular}

TABLE 21

Revision and editing

\begin{tabular}{|l|c|}
\hline Yes & $90 \%$ \\
\hline It depends on time & $8 \%$ \\
\hline It depends on who the client is & $2 \%$ \\
\hline No & $1 \%$ \\
\hline It depends on money & $0 \%$ \\
\hline
\end{tabular}

In conjunction with our findings that $37 \%$ of respondents chiefly translate for professional or personal satisfaction, that $72 \%$ always do their best and that $48 \%$ refuse to lower their rates, these results attest to translators' professional self-respect and emphasis on the quality of their own translations. It will be interesting to see if these claims correspond to reality.

TABLE 22

Usefulness of theory

\begin{tabular}{|l|r|}
\hline Yes & $68 \%$ \\
\hline I am not familiar with translation theory & $17 \%$ \\
\hline Other & $8 \%$ \\
\hline No & $7 \%$ \\
\hline
\end{tabular}

As we mentioned above, we consider these results a pleasant surprise. How such "theoretical optimism" is reflected in the quality of the analysed translations remains to be seen. Interestingly, the "Other" field was mainly marked by respondents with translation degrees, who have surely been exposed to theory. The following answer from one of the respondents was perhaps the most interesting observation:

It's relative. Those familiar with translation theory often claim it isn't applicable in practice. But of course they are much better translators than the ones who lack a theoretical background. Translation theory is a solid basis for a novice translator, but it has no influence on their subsequent professional development. The situation regarding literary translation is surely quite different. (my translation) ${ }^{20}$

This respondent emphasizes the importance of the type of translated text and the translator's particular method. This will also be an interesting area to observe in the correlation analysis.

In this section we have presented only isolated responses to individual survey questions and attempted to briefly interpret them. In the next section, we will test 
our hypotheses regarding potential correlations and see how individual responses correspond to the translators' practical performance. In the qualitative analysis we will evaluate the quality of commercially translated texts using the methods we have described. It will be interesting to compare the respondents' answers and the actual quality of their translations. We are naturally aware that the results of our study may not be entirely objective, as suggested by one of the comments to question 25: "By the way, it irritates me that your questionnaire requires answers but doesn't always offer an 'Other' option" (my translation). ${ }^{21}$ We nonetheless expect that our results may prove useful to the theory, as well as the didactics of translations, along with providing similar future studies the opportunity to react to our work, formulate new hypotheses or refine our methods.

In the ensuing section we will delve into the testing and interpreting of our correlation hypotheses.

\subsection{Correlation analysis}

On the basis of our specified methods, we shall now proceed to the testing and interpretation of our hypotheses. In some cases it might seem that the sample size is not sufficient to make some strong affirmations. However, most of the claims were further verified by personal interaction with practising translators and professional organisations and by applying the principle of data triangulation.

\subsubsection{H1: Older translators charge higher rates than younger translators}

TABLE 23

Correlation between price and age

\begin{tabular}{|l|c|c|c|c|c|c|}
\hline INDICATOR A: Price & Less than $€ 7$ & $€ 7-10$ & $€ 11-15$ & $€ 16-20$ & More than $€ 20$ & Total \\
\hline INDICATOR B: Age & & & & & & \\
\hline Less than 31 years old & 3 & 33 & 28 & 4 & 1 & 69 \\
\hline 31-40 years old & 4 & 19 & 15 & 4 & 3 & 45 \\
\hline More than 40 years old & 2 & 9 & 6 & 6 & 1 & 24 \\
\hline Total & 9 & 61 & 49 & 14 & 5 & 138 \\
\hline
\end{tabular}

Statistic $\chi^{2}(11.4485)<\chi^{2}(15.50731306)$ critical

Hypothesis rejected

There is not sufficient empirical data to confirm our proposed hypothesis regarding connections among the variety of responses to the survey questions. The questionnaire data treated in the contingency table display negligible variation among the respondents' answers. The distinctions that are present are statistically insignificant and there is thus no ground to confirm the hypothesis. It follows that age does not directly correlate with financial compensation, and we thus predict that neither does longer experience in the field. 
3.2.2. H2: Respondents who have studied translation charge higher rates than those with other educational backgrounds

TABLE 24

\section{Correlation between price and education}

\begin{tabular}{|l|c|c|c|c|c|c|}
\hline Indicator: education & \multicolumn{5}{|c|}{ Indicator: price } & \\
\hline $\begin{array}{l}\text { Education } \\
\text { (field of study) }\end{array}$ & Less than $€ 7$ & $€ 7-10$ & $€ 11-15$ & $€ 16-20$ & More than $€ 20$ & Total \\
\hline Translation studies & 2 & 27 & 25 & 4 & 4 & 62 \\
\hline $\begin{array}{l}\text { Other than } \\
\text { translation studies }\end{array}$ & 7 & 35 & 25 & 9 & 1 & 77 \\
\hline Total & 9 & 62 & 50 & 13 & 5 & 139 \\
\hline
\end{tabular}

Statistic $\chi^{2}(5.98409467)<\chi^{2}(9.487)$ critical

Hypothesis rejected

It follows that there is no direct relationship between education and financial compensation. This was also confirmed by the results of the qualitative analysis, where all four such translators (with degrees in translation) in the sample asked less than $€ 10$ per standard page, one participant with a teaching degree asked $€ 9$ (after coming to an agreement; her standard rate is $€ 12$ or more) and the rest of the participants asked $€ 15$ or more. In fact, their high rates were the reason why we could not include more participants without translation degrees in the sample. Allow us to reiterate the quote from one of the participant's emails to us: "I try to adhere to recommended rates, which are between $€ 21$ and $€ 22$ per standard page (1800 keystrokes) here in Slovakia. This price is only half of the EU standard. $€ 10$ reflects prices circa 15 years ago" (my translation). ${ }^{22}$ We have doubts as to the alleged prevalence of such rates in Slovakia, when the law dictates a rate of $€ 20$ per standard page for sworn translators. In any case, it is safe to say that formally educated translators are more modest and at the same time aware of what can occur during the translation process. Translators who ask $€ 20$ per standard page ought to produce translations of corresponding quality. Our sample included one such a translator; we shall evaluate her performance in the qualitative analysis. The author of the above email referring to EU standards was presumably unaware that wages in Slovakia are several times less than the EU average.

\subsubsection{H3: Respondents who translate less widely used languages charge higher} rates than those who translate English or German

TABLE 25

\section{Correlation between price and translated language}

\begin{tabular}{|l|c|c|c|c|c|c|}
\hline $\begin{array}{l}\text { Indicator: translated } \\
\text { languages }\end{array}$ & \multicolumn{5}{|c|}{ Indicator: price } & \\
\hline Translated language & Less than $€ 7$ & $€ 7-10$ & $€ 11-15$ & $€ 16-20$ & More than $€ 20$ & Total \\
\hline English and German & 9 & 38 & 25 & 4 & 1 & 77 \\
\hline Other languages & 0 & 15 & 20 & 10 & 4 & 49 \\
\hline Total & 9 & 53 & 45 & 14 & 5 & 126 \\
\hline
\end{tabular}

Statistic $\chi^{2}(18.6046417)>\chi^{2}(9.487)$ critical

Hypothesis impossible to reject 
Translators of less widely used languages charge higher rates than translators of English or German. One obvious explanation for this is the sheer number of people who, regardless of their qualifications, venture to translate these languages.

\subsubsection{H4: Respondents who have studied translation consider translation}

theory more useful than do those with other educational backgrounds

TABLE 26

Correlation between theory knowledge and field of study

\begin{tabular}{|l|c|c|c|}
\hline Indicator: & \multicolumn{2}{|c|}{ Indicator: USEFULNESS of theory } & Total \\
\hline $\begin{array}{l}\text { Education } \\
\text { (field of study) }\end{array}$ & Yes & No and Other & 63 \\
\hline Translation studies & 56 & 29 & 74 \\
\hline $\begin{array}{l}\text { Other than } \\
\text { translation studies }\end{array}$ & 45 & 36 & 137 \\
\hline Total & 101 & & \\
\hline
\end{tabular}

Statistic $\chi^{2}(13.848531)>\chi^{2}(3.8414591)$ critical

Hypothesis impossible to reject

Translators with a degree in translation have a more positive attitude to theory than their counterparts without one. It is interesting to once again note that it is chiefly the respondents who have studied translation who, in the "Other" field, specified the particular contexts in which they find theory useful. This attests to their thoughtful treatment of this particular aspect of their profession. On the other hand, it will also be interesting to observe the results of $\mathrm{H} 6$ in this light.

3.2.5. H5: Respondents with tertiary education are more likely to take a comprehensive process-based approach to translation than those without it

TABLE 27

Correlation between education and method of translation

\begin{tabular}{|l|c|c|c|}
\hline Indicator: Education & \multicolumn{2}{|c|}{ Indicator: METHOD of translation } & \\
\hline & Comprehensive & Other than comprehensive & Total \\
\hline University degree & 24 & 93 & 117 \\
\hline Other & 3 & 13 & 16 \\
\hline Total & 27 & 106 & 133 \\
\hline
\end{tabular}

Statistic $\chi^{2}(0.027034)<\chi^{2}(3.841459)$ critical

Hypothesis rejected

There is no direct relationship between level of education and approach to the translation process. In response to the question, $80 \%$ of respondents claimed that they skim the text before translating, that they simply start translating immediately and address problems as they arise, or that it depends on time or compensation. This finding provides more support for our supposition that the translations we analysed in the qualitative portion of the study will be characterized by a high degree of literalness, a lower degree of thoughtfulness and a lower degree of interpretation in texts where the latter is vital to success. 
3.2.6. H6: Respondents who consider translation theory useful are more likely to take a comprehensive process-based approach to translation than those who do not consider it useful

TABLE 28

Correlation between Usefulness of theory and the method of translation

\begin{tabular}{|l|c|c|c|}
\hline Indicator: & \multicolumn{2}{|c|}{ Indicator: METHOD of translation } & \\
\hline USEFULNESS of theory & Comprehensive & Other than comprehensive & Total \\
\hline Yes & 22 & 70 & 92 \\
\hline No and Other & 2 & 31 & 33 \\
\hline Total & 24 & 101 & 125 \\
\hline
\end{tabular}

Statistic $\chi^{2}(4.9896973)>\chi^{2}(3.8414591)$ critical

Hypothesis impossible to reject

Those respondents who consider translation theory useful also apply it in practice. These results make for a particularly interesting comparison with those of translation and interpreting student (Tešlárová 2011), in whose study $78.57 \%$ of third-year students read their text before translating it, but only $14.29 \%$ conducted a text analysis. These findings merit further reflection. In any case, our result appears to indicate that translators with degrees in translation will proceed more thoughtfully and therefore with more versatility. We shall see if this supposition is borne out in the study's qualitative portion.

3.2.7. H7: Younger translators are more likely to lower their rates in response to competitive pressure than older translators

TABLE 29

Correlation between age and competitive pressure

\begin{tabular}{|c|c|c|c|c|}
\hline \multicolumn{4}{|c|}{ Indicator A: COMPETITIVE PRESSURE } & \multirow[b]{2}{*}{ Total } \\
\hline & I lower my rates & I don't lower my rates & Other & \\
\hline \multicolumn{5}{|l|}{ INDICATOR B: Age } \\
\hline Up to 30 years old & 6 & 39 & 25 & 70 \\
\hline $31-40$ years old & 4 & 21 & 19 & 44 \\
\hline More than 40 years old & 3 & 13 & 8 & 24 \\
\hline Total & 13 & 73 & 52 & 138 \\
\hline
\end{tabular}

Statistic $\chi^{2}(1.1805)<\chi^{2}(9.487729037)$ critical

Hypothesis rejected

There is no direct relationship between lowering price in response to competitive pressure and age. That said, we are interested to see if any correlation between language and competitive pressure exists. It nonetheless seems that among price, education, age and language, education is the most significant factor working against translators with degrees in translation. This has been indicated by the correlation analysis, follow up interviews, questionnaires as well as qualitative analysis. However odd it may seem, it indicates that at least in Slovakia, some traditionally accepted paradigms need to be reevaluated. This situation can also be supported by the analysis of the European status of translators conducted by Pym, Grin et al. who claims that 
[t]his means that some good translators may not be paid what they deserve. When this happens, good translators will logically leave the translation market and take up other forms of academic activity, in a process known as "adverse selection" (Pym, Grin et al. 2012:15).

3.2.8. H8: Respondents who have studied translation are younger than those with other educational backgrounds

TABLE 30

Correlation between the field of study and age

\begin{tabular}{|c|c|c|c|c|}
\hline \multicolumn{3}{|c|}{ Indicator A: FIELD OF STUDY } & \multirow[b]{2}{*}{ Other } & \multirow[b]{2}{*}{ Total } \\
\hline & Translation studies & $\begin{array}{c}\text { Other than } \\
\text { translation studies }\end{array}$ & & \\
\hline \multicolumn{5}{|l|}{ INDICATOR B: AGE } \\
\hline Up to 30 years old & 46 & 22 & & 68 \\
\hline $31-40$ years old & 9 & 35 & & 44 \\
\hline More than 40 years old & 4 & 20 & & 24 \\
\hline Total & 59 & 77 & & 136 \\
\hline
\end{tabular}

Statistic $\chi^{2}(32.691)>\chi^{2}(27.63102112)$ critical

Hypothesis impossible to reject

These results point to the fact that the abundance of new institutions offering translation studies have begun to bear fruit, although flooding the market with ostensibly qualified translators can confuse clients and weaken signalling mechanisms. We consider this a positive indication although, as stated earlier, and we expect this to be borne out by the qualitative analysis as well, formal translation education is no guarantee of a quality translation, but rather a precondition of one. It would be interesting to conduct a similar study in ten years, for example, to observe the relevant circumstances and their development.

3.2.9. H9: Respondents whose translation work is not primarily motivated by financial gain take a more comprehensive approach to translation than those who are primarily motivated by financial gain

TABLE 31

Correlation between method of translation and motivation

\begin{tabular}{|l|c|c|c|}
\hline Indicator A: & \multicolumn{2}{|c|}{ Indicator B: METHOD of translation } & \\
\hline MOTIVATION & Comprehensive & Other than comprehensive & Total \\
\hline Motivated by financial gain & 6 & 30 & 36 \\
\hline $\begin{array}{l}\text { Not motivated by financial } \\
\text { gain and Other }\end{array}$ & 18 & 76 & 94 \\
\hline Total & 24 & 106 & 130 \\
\hline
\end{tabular}

Statistic $\chi^{2}(0.10655025)<\chi^{2}(3.84145915)$ critical

Hypothesis rejected

We found no direct relationship between motivation and method of translation. While processing the data into the tables, however, we did notice a correlation between price and method of translation, specifically that those translators with rates higher than $€ 20$ per standard page tended to prioritize a comprehensive approach 
to translation, though they were also translators of less widely-used languages, who generally have more time and are faced with less competition (H1). We don't think that the problem we face is what translators should know and if they do know it (have sufficient competence, although as has been pointed out demand for competence changes rapidly) they deserve better pays. The problem is what translators think they know and how they are able to persuade clients on their knowledge. We assume that "uneducated" translators think they know more than they do simply because they don't know what they don't know and thus they are more confident when negotiating with clients.

\subsubsection{H10: Translators of less widespread languages are less likely to lower their rates in response to competitive pressure than translators of English and German}

TABLE 32

\section{Correlation between competitive pressure and translated language}

\begin{tabular}{|l|c|c|c|}
\hline Indicator A: & \multicolumn{2}{|c|}{ Indicator B: Competitive pressure } & \\
\hline Translated language & I lower my rates & I don't lower my rates and Other & Total \\
\hline English and German & 8 & 57 & 65 \\
\hline Other languages & 5 & 56 & 61 \\
\hline Total & 13 & 113 & 126 \\
\hline
\end{tabular}

Statistic $\chi^{2}(0.57475)<\chi^{2}(3.84146)$ critical

Hypothesis rejected

Translators, disregarding the various factors that influence their work, do not generally lower their rates, which we consider a positive sign, possibly indicating a trend towards the rising social standing of translators and interpreters. However, we realize that with changing market conditions the situation will keep evolving rapidly in either direction.

\section{Conclusion}

To sum up, our results allow us to sketch a rough profile of the average person who translates in Slovakia. In fact, we expect that the following profile could be applied to the entirety of Central Europe. We are aware of the fact that the model we outline might be regarded as schematic disregarding various distinct specifics of translation profession, but we believe that when we are able to grasp a picture of average, it will enable to us to better analyze centers and peripheries of translation studies.

The average Slovak translator is a woman in her late twenties/early thirties with a university education in a field other than translation/interpreting. She specializes in non-literary texts and translates predominantly from English. If she does in fact use translation software, then she shows a high level of competence with Trados and computers in general. She is self-employed and normally charges by the standard page, for which she asks $€ 15$ if she does not work for a translation agency. Her work is primarily motivated by financial gain, as well as professional and personal satisfaction. She always works at full capacity, only refusing a job due to shortage of time or inadequate pay. Time does not generally affect her work negatively, though when pressed for time her work does suffer due to stress. While she does consider translation theory 
useful, she does not have time to apply it to her work. Instead she gives the text a cursory reading, or none at all, simply addressing issues as they appear. She rarely asks about the purpose of the translation, and consequently her translations are often literal and in places unnatural.

In this paper we were not interested in what translators should do or should be, but in what they do and who they are. We believe that such a profile may help us, at least in Slovakia, see not only what is demanded by the market but also how and why translation programs taught at the universities do not reflect market demand to a full extent. It can also help us explain why the social status of translators is generally low and that the situation will probably get even more critical in the future. If we continue to observe how the situation of translators develops in time, we will also be able to trace subconscious ideological influences that affect translators' work. Universities should not be market slaves, however, we need to make our students aware of what they may expect once/if they decide to work in the translation market (similar recommendations emerged from the OPTIMALE survey). Findings also warn us that traditionally accepted paradigms and ideas need to be seriously reevaluated. We are aware that all results of such research may elicit objections, but we hope that it will foster more research that can shed more light on the individuals who contribute to the creation of cultures.

\section{NOTES}

1. Detailed qualitative analyses of translations may be found in our book Kto, čo, ako a za akých podmienok prekladá: prekladatel'v kontexte doby (See Djovčoš 2012).

2. Jettmarová, Zuzana (28 March 2013): email communication.

3. “predlohu/východiskový text môžeme chápat ako „siet’ nekonečných variantov príjmu. Je to množina potenciálnych významov ústiacich do komplexného zmyslu“ a prichádza k záveru, že „žiadny vzorec na prekladanie či na „dokonalý “ preklad preto neexistuje“.”

4. EMT EXPERT Group (2009): Competences for professional translators, experts in multilingual and multimedia communication. Brussels: EMT, 4-7. Visited on 20 September 2012, <http://ec.europa. eu/dgs/translation/programmes/emt/key_documents/emt_competences_translators_en.pdf >.

5. "ak uvedené texty prekladá prekladatel', ktorého kompetencie narábania s cielovým jazykom slovenčinou sú nedostatočné a chýbajú mu základné teoretické poznatky z translatológie, môže spôsobit nekomunikatívnost prekladu a jeho následné odmietnutie cielovým recipientom."

6. Erasmus Network for Professional Translator Training. Optimising Professional Translator Training in a Multilingual Europe (OPTIMALE). Competence requirements: Visited on 30 October 2012, $<$ http://www.translator-training.eu/competences-requirements $>$.

7. Edotaznik (Last update: this page used to work like a Survey Monkey and does not exist anymore) Created on June 2010, <http://www.edotaznik.sk>.

8. ProTranslator (Last update: May 2010 ): Visited on 23 October 2012, <http://www.protranslators. eu>.

9. Pont Francophone: Association francophone des étudiants slovaques de la Faculté des Lettres de l'Université Comenius: Visited on October 2011, <http://www.pontfrancophone.sk>.

10. ProZ: Visited on February 2011, <http://www.proz.com>.

11. Slovak Society of Translators of Scientific and Technical Literature (SSPOL): Visited on August 2010, $<$ http://www.sspol.sk $>$.

12. Prekladatelia (Last update: July 2014): Visited on July 2010, <http://www.prekladatelia.com $>$.

13. Currently, five Slovak universities offer translation and interpreting programmes (Prešov, Banská Bystrica, Nitra, Bratislava and Košice). However, other universities are applying for the permission to teach translation and interpreting. Such a situation might be rather confusing for possible clients, who receive too many signals (by signaling mechanisms we mean those as defined by Pym, Grin et al. 2012: 15), which are not reliable enough. Slovakia is the only country in the EU that guarantees translators some kind of legal protection. It means that since the 2007 amendment to the 
Trades Licensing Act No. 455/1991, translation became a licensed trade. It also means that if you are to work as a commercial translator with the right to issue an invoice (this doesn't involve court translators who are subject to Act No. 382/2004), you must provide proof of your competence. More on this issue can be found on page 51 of the Trade Licensing Act Federal Assembly of the Czech and Slovak Federative Republic (1991/2011): 455/1991 Coll. ACT of 2 October 1991 on Trade Licensing (Trade Licensing Act). Amended Version. Visited on 10 February 2012, <www. minv.sk/?trade-licencing\&subor=39253>.

14. Erasmus Network for Professional Translator Training (2011): The OPTimalE employer survey and consultation, 8-9.Visited on 30.10.2012, <http://www.translator-training.eu/attachments/article/52/WP4_Synthesis_report.pdf>.

15. By the term Trade license we mean a definition in line with the Trades Licensing Act No. 455/1991 that was amended in 2007. See note 12 for more information.

16. “[...] závisí to od viacerých okolností, resp. druhu stresovej zátaže, vo všeobecnosti pod stresom nepracujem, najskôr sa ho snažím prekonat, pričom niekedy stačí chvílka.“

17. “Snažím sa držat’ odporúčaných cien - čo u nás predstavuje $21-22 €$ za NS (1800 úderov). Táto cena je stále polovičná v porovnaní so štandardom v EÚ. Cena $10 €$ odpovedá cene spred 15 rokov. (8.07.2011): email communication.

18. "Necítim potrebu pohybovat' cenou smerom nadol, pretože moja kombinácia odbornosti, kvality môjho prekladu a používaných CAT nástrojov je na Slovensku ojedinelá."

19. EN 15038 is a European quality standard for translation services approved in 2006 by the European Committee for Standardization (CEN).

20. “To je relatívne. Ti, ktorí teóriu prekladu poznajú, často tvrdia, že je v reáli nepoužitel’ná. Samozrejme, sú však ovela lepšími prekladatel’mi ako tí, ktorí ju nepoznajú. Teória prekladu je dobrá báza pre prekladatela v počiatkoch jeho práce, ale jeho d’alší profesionálny rozvoj už nijako neovplyvňuje. Samozrejme, iná je situácia pri preklade umeleckých textov."

21. "Mimochodom, irituje ma Váš dotazník, v ktorom sú povinné odpovede, ale ani jedna $\mathrm{z}$ nich nie je použitelná a nie je možnost̉ odpovede "Iné."

22. “Snažím sa držat’ odporúčaných cien - čo u nás predstavuje 21 - $22 €$ za NS (1800 úderov). Táto cena je stále polovičná v porovnaní so štandardom v EÚ. Cena $10 €$ odpovedá cene spred 15 rokov. (8.07.2011): email communication.

\section{REFERENCES}

BeLL, Thomas, Roger (1991): Translation and translating: theory and practice. London: Longman. BednárovÁ, Katarína (1994): Miesto a funkcia prekladu v kultúre národa. Metodologické poznámky $\mathrm{k}$ dejinám prekladu [Place and Function of Translation in the Culture of a Nation. Notes on Methodology of Translation History]. In: K otázkam teórie a dejín prekladu na Slovensku II [On Theory and History of Translation in Slovakia II]. Bratislava: Institute of World Literature SAS, 8-29.

Biloveskŕ, Vladimír (2011): Zázraky v orechovej škrupinke: Prekladové konkretizácie tvorby S. W. Hawkinga v slovenskom kultúrnom priestore [Miracles in a Nutshell: How Translation of Hawking Resonated in the Slovak Cultural Space ]. Banská Bystrica: Matej Bel University.

Djovčoš, Martin (2012): Kto, čo a za akých podmienok prekladá: prekladatel' v kontexte doby [Who, what, how and under which circumstances translates: translators in the context of their time]. Banská Bystrica: Matej Bel University.

Djovčoš, Martin and Pliešovská, Lubica (2011): Power and Shifting Paradigm in Translation. Mutatis Mutandis. 4(1):77-88. Visited on 15 March 2011, <http://revinut.udea.edu.co/index.

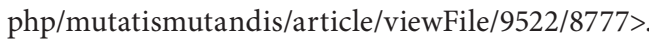

FERENČík, Ján (1982). Kontexty prekladu [Contexts of Translation]. Bratislava: Slovenský spisovatel.

Fock, Holger, De HaAn, Martin and Lhotová, Alena (2008): Comparative income of literary translators in Europe. (Last update 05 December 2008). Brussels: CEATL. Visited on 30 April 2012, <http://www.ceatl.eu/docs/surveyuk.pdf>.

Fugová, Katarína (2011): Who is Translator. Bachelor thesis, unpublished. Banská Bystrica: Matej Bel University. 
Gentzler, Edwin (2001): Contemporary translation theories. Clevedon: Multilingual Matters. Gromová, Edita (1996): Interpretácia v procese prekladu [Interpretation in the Process of Translation]. Nitra: Vysoká škola pedagogická [College of Education].

Gromová, Edita (2003): Teória a didaktika prekladu [Theory and Didactics of Translation]. Nitra: Constantine the Philosopher University.

Guerberof-Arenas, Ana (2009): Productivity and Quality in the Post-editing of Outputs from Translation Memories and Machine Translation. Localisation Focus. 7(1):11-21. Visited on 20 August 2013, <http://isg.urv.es/library/papers/2009_Ana_Guerberof_Vol_7-11.pdf>.

HuŤKová, Anita (2011): A fordítás eredetisége [Translation of the Original]. Alkalmazott nyelvészeti közlemények [Journal of Applied Linguistics]. 6(1):81-89.

Jettmarová, Zuzana (2008): Czech and Slovak Translation Theories: the Lesser-known Tradition. In: Jana Králová, Zuzana JetTMArová et al., eds. Tradition versus Modernity: from the Classic Period of the Prague School to Translation Studies at the Beginning of the $21^{\text {st }}$ Century. Prague: Charles University, 15-46. Visited on 20 March 2013, <http://usuaris. tinet.cat/apym/publications/ETT/Jettmarova_4\%2002_08.pdf $>$.

Katan, David (2009): Translation Theory and Professional Practice: A Global Survey of the Great Divide. In: Helle V. Dam and Karen Korning Zethsen, ed. Translation studies: Focus on the translator. Special Issue. Hermes. 42:111-153. Visited on 17 April 2011, <http://download1.hermes.asb.dk/archive/download/Hermes-42-7-katan_net.pdf>.

Keníž, Alojz (2008): Preklad ako hra na ekvivalenciu a invariant [Translation as an Interplay between Equivalence and Invariance ]. Bratislava: AnaPress.

Kusá, Mária (2005): Preklad ako súčast dejín kultúrneho priestoru [Translation as a Part of Cultural History]. Bratislava: Institute of World Literature SAS.

LevÝ, Jiří (1963): Umění překladu [The Art of Translation]. Prague: Panorama.

Müglová, Daniela (2009): Komunikácia, tlmočenie, preklad, alebo, Prečo spadla Babylonská veža? [Communication, Interpreting, Translation or Why the Tower of Babel Collapsed]. Bratislava: Enigma.

Popovič, Anton (1975): Teória umeleckého prekladu. Aspekty literárnej metakomunikácie [Theory of Artistic Translation. Aspects of Literary Metacommunication]. Bratislava: Tatran.

PyM, Anthony (2010): Exploring Translation Theories. London/New York: Routledge.

Pym, Anthony, Grin, François, Sfreddo, Claudio et al. (2012): The status of the translation profession in the European Union. Brussels: DGT. Visited on 12 June 2013, <http://ec.europa. eu/dgs/translation/publications/studies/translation_profession_en.pdf $>$.

Pyм, Anthony (2013): Translation skill-sets in a machine-translation age. Meta 58(3):487-503.

Sharp, Bernadette, Zock, Michael, Carl, Michael et al. eds. (2011): Proceedings of the $8^{\text {th }}$ International NLPCS Workshop; Special theme: Human-Machine Interaction in Translation. (Copenhagen, 20-21 August 2011). Copenhagen: Samfundslitteratur. Visited on 10 May 2013, <http://bridge.cbs.dk/events/CSL_41_complete.pdf >.

SiHELSKÝ, Boris (2008): Ako robit pedagogický výskum: Meranie a kvantifikácia premenných [How to Design Pedagogical Research: Measuring and Quantification of Variables ]. Učebný text k vzdelávaciemu programu 72-KSU-2, 4. chapter [Instruction to Educational Program]. Banská Bystrica: MPC.

Teixeira, Carlos (2011): Knowledge of Provenance and its Effects on Translation Performance in an Integrated TM/MT Environment. In: Bernadette SHARP, Michael Zock, Michael CARL et al. eds. Proceedings of the $8^{\text {th }}$ International NLPCS Workshop; Special theme: HumanMachine Interaction in Translation. (Copenhagen, 20-21 August 2011). Copenhagen: Samfundslitteratur, 107-118. Visited on 15 June 2013, <http://bridge.cbs.dk/events/CSL_41_ complete.pdf $>$.

TešLÁrová, Zuzana (2011): Translation Process in Slovakia and in the Western World. Bachelor thesis, unpublished. Banská Bystrica: Matej Bel University.

Тумосzко, Maria (2007): Enlarging translation, empowering translators. Manchester: St. Jerome Publishing. 
VANDE WALLE, Jean-Marie (2007): Le Traducteur et la technique: un couple infernal. In: Maria Teresa Musacchio et Geneviève Henrot Sostero, eds. Tradurre: formazione e Professione. Padua: Cleup, 31-44.

VenUt, Lawrence (1998): Scandals of translation: towards an ethics of difference. London/New York: Routledge.

Vilıkovský, Ján (1984): Preklad ako tvorba [Translation as Creation]. Bratislava: Slovenský spisovatel'.

YAMADA, Masaru (2011): The effect of translation memory databases on productivity. In: Anthony Pyм, ed. Translation research projects 3. Tarragona: Intercultural Studies Group. Visited on 13 June 2013, <http://isg.urv.es/publicity/isg/publications/trp_3_2011/yamada. pdf $>$. 